\title{
Advances and Prospects in Cancer Immunotherapy
}

\author{
Juhua Zhou \\ Institute for Tumor Immunology, Ludong University School of Life Sciences, 186 Hongqi Middle Road, Yantai, Shandong 264025, China
}

Correspondence should be addressed to Juhua Zhou; juhua.zhou@gmail.com

Received 9 December 2013; Accepted 11 February 2014; Published 13 March 2014

Academic Editor: Jordi Camps

Copyright (c) 2014 Juhua Zhou. This is an open access article distributed under the Creative Commons Attribution License, which permits unrestricted use, distribution, and reproduction in any medium, provided the original work is properly cited.

\begin{abstract}
Cancer immunotherapy is a promising and effective treatment modality for patients with cancers. Cytokine, anticytokine, and antibody therapies appear to be effective in treating various forms of cancer. The human papillomavirus vaccine is protective for cervical cancer, and this discovery has paved the way to the development of cancer vaccines for other forms of virus-associated cancers such as liver cancer and Merkel cell carcinoma. Clinical trials have demonstrated that adoptive cell therapy using tumorinfiltrating lymphocytes can induce tumor regression in approximately $75 \%$ of metastatic melanoma patients, suggesting the possibility of using similar technique to effectively treat breast, lung, and renal cancers in the near future. Besides, genetically engineered $\mathrm{T}$ cells transduced with genes encoding specific $\mathrm{T}$ cell receptors and chimeric antigen receptors have been shown effective in the treatment of cancer patients. These studies suggest that combination therapies are superior choices in cancer immunotherapy for patients.
\end{abstract}

\section{Introduction}

Cancer develops when abnormal cells grow uncontrollably and spread in human body. Different from normal cells, cancer cells have two unique characteristics, that is, uncontrolled growth and metastasis. Recent studies have shown that cancer cells have eight hallmarks, including sustaining proliferative signaling, evading growth suppressors, resisting cell death, enabling replicative immortality, inducing angiogenesis, activating invasion and metastasis, reprogramming of energy metabolism, and evading immune destruction [1]. Usually, gene mutations induced by intrinsic factors and/or exogenous factors result in the production and growth of cancer cells. It has been estimated that new cases of cancer are 1.66 million and deaths from cancer are 0.58 million in the United States in 2013 [2]. It is expected that there will be 20-30 million new cases of cancer and 13-17 million people will die from caner all over the world by 2030 [3]. At present, cancer is the most serious health problem worldwide [4].

Cancer treatment is still a challenging task to both scientists and clinicians. Currently, cancer is usually treated with surgery $[5,6]$, radiation $[7,8]$, chemotherapy $[9,10]$, hormone therapy [11], biological therapy [12,13], and targeted therapies [14-16]. However, no method available presently for cancer treatment is satisfactory [17]. With the advancement in immunological science and related disciplines, immunotherapy is becoming a new promising method for cancer treatment [18-21]. In this paper, the history, current status, and prospects of immunotherapy for cancer treatment are discussed.

\section{Cancer Development}

Cancer results from uncontrolled proliferation of aberrant cells in the body. However, the mechanisms of cancer development have not been fully understood. Early studies have shown that cancer development is a multistep process [22]. In this hypothesis, normal cells gradually become malignant through a progressive series of alterations resulting from the actions of two or more oncogenes due to gene mutations [23]. The multistep nature of cancer development has been evidenced in prostate cancer, colorectal cancer, breast cancer, acute lymphoblastic leukemia (ALL), acute myelogenous leukemia (AML), and myeloproliferative disorders [24, 25]. Generally, the multistep of cancer development includes initiation, promotion, and progression [22]. The multistep hypothesis of cancer development has an implication in 
cancer treatment in that the early neoplastic cells may be effectively interrupted before the malignant cells come out.

In 1976, Nowell proposed clonal evolution hypothesis to explain cancer development [26]. He proposed that cancer develops by a repetitive process of clonal expansion and clonal selection within the tissue ecosystems in human body. He also proposed that clonal evolution hypothesis may have great implications in cancer treatment as cancer treatment may destroy cancer clones and corrode cancer habitats. However, it may unwittingly produce selection pressure for the clonal expansion of resistant cancer cells [27]. For instance, there are numerous genetic subclones of leukemia-initiating cells in ALL patients [28]. Analysis of AML patients' samples showed relapsed AML after chemotherapy, demonstrating the generation and presence of a primary clone [29]. Furthermore, analysis of paired persistent AML samples revealed cancer patients with 2 concomitant dominant clones; one was chemotherapy sensitive and another resistant [29]. There is a report demonstrating that recurrent high-grade serous carcinoma (HGSC, a form of ovarian cancer) also originates from multiple clones in the primary tumor during standard treatment [30].

Cancer stem cell (CSC) hypothesis, on the other hand, was initially proposed to explain the observation of tumor heterogeneity [31]. Also, CSCs may cause the generation of tumors in the same way as that of normal stem cells. Moreover, CSCs are capable of self-renewal and differentiation into multiple cell types in tumors, persist in tumors, and cause relapse and metastasis. Early studies indicated that CSCs might play a role in breast cancer development $[32,33]$. It was demonstrated that $\mathrm{CD} 34^{+} \mathrm{CD} 38^{-}$cells were CSCs of leukemia, which could initiate tumors in NOD/SCID mice [34]. At present, CSCs have been identified in many types of cancers such as brain cancer [35], breast cancer [36], colon cancer [37], liver cancer [38], lung cancer [39], ovary cancer [40], prostate cancer [41], pancreas cancer [38], gastric carcinogenesis [42], leukemia [43], melanoma [44], and oral carcinoma [45]. Cancer stem cell hypothesis has great implications in the identification of cancers, selection of cancer drug targets, prevention of cancer metastasis, and development of new treatment modalities.

\section{Interactions between Cancer and the Immune System}

The immune system, including innate immune system and adaptive immune system, is composed of special factors, cells, tissues, and organs. It has been well known that the immune system can detect a wide variety of infectious organisms and other invaders, distinguish them from the own healthy cells and tissues, and prevent infections [46].

It has been documented that there is interaction between the immune system and cancer as evidenced by cancer immunosurveillance theory [47-50]. Cancer immunosurveillance refers to the monitoring function of the immune system in cancer development. There are studies that have demonstrated that the immune system can recognize and eliminate aberrant cancer cells arising within the human body [51-56]. Thus, the interaction between cancer and the immune system plays a pivotal role in cancer development. In cancer patients, the immune system is not sufficiently vigorous to eliminate cancer cells, suggesting that the antitumor immune system is suppressed. For instance, transplant recipients under continued immunosuppression displayed a significantly higher risk of developing de novo tumors such as lung cancer [57] and noticeably increased risk for cervical cancer in immunosuppressed women [58].

It has been shown that several factors may contribute to antitumor immunosuppression, for instance, a low frequency of high-avidity antitumor $\mathrm{T}$ cells, presence of $\mathrm{CD} 4^{+} \mathrm{CD} 25^{+}$ regulatory $\mathrm{T}$ (Treg) cells, and various strategies of cellularmediated tumor-induced immune evasion [59]. Antitumor immunosuppression may also result from soluble factors and altered antigenicity [60]. For instance, tumor-derived interleukin (IL)-18 induced immunosuppression in NK cellcontrolled cancers $[61,62]$. IL- $1 \alpha$ upregulated TGF-beta in mesenchymal stem cells and thus induced immunosuppression, leading to the growth of prostate cancer cells [63]. Therefore, immunological methods that eliminate antitumor immunosuppression and/or increase antitumor immunity can be very useful in the treatment of cancer.

\section{Cytokine and Anticytokine Therapy}

Cytokines are group of proteins, including interleukins and growth factors, which play an important role in the regulation of the immune system [64]. Several studies have indicated that cytokine therapy could relieve immunosuppression in cancer patients [65] and therefore, cytokine therapy has the potential used in cancer treatment.

Interferon (IFN)- $\alpha$ was the first cytokine, which was approved and used for leukemia $[66,67]$ and melanoma patients $[68,69]$. IFN- $\alpha$ therapy turned out to be an effective method for the treatment of leukemia and melanoma. At present, IFN- $\alpha$ therapy remains the first choice for the treatment of metastatic melanoma [70]. There are efforts to improve the efficacy of IFN- $\alpha$ therapy for cancer treatment. To this end, efforts are to develop a combination therapy, a combination of IFN- $\alpha$ therapy with other treatment modalities such as chemotherapy that can be more effective in the treatment of cancer [71].

In 1998, the US Food and Drug Administration (FDA) approved interleukin-2 (IL-2) therapy for cancer treatment. Thus, IL-2 was the second cytokine used in cancer treatment. Clinical trials demonstrated that IL-2 therapy was effective in the treatment of patients with solid tumors such as metastatic melanoma and renal cell carcinoma [72]. The combination therapies of IL-2 with other cytokines such as granulocytemacrophage colony-stimulating factor (GM-CSF) [73] or the sequence-specific combination of IL-2 therapy with chemotherapy such as temozolomide [74] appeared to be more beneficial in cancer treatment.

Tumor necrosis factor (TNF)- $\alpha$ has also been shown to have antitumor activity [75], suggesting a therapeutic value for the treatment of cancer [76]. TNF- $\alpha$ was used to treat patients with advanced solid tumors. However, the use and 
efficacy of TNF- $\alpha$ therapy for cancer treatment are controversial [77]. Recent studies showed that there was an association between the anti-TNF treatments such as adalimumab for noncancer patients and incidence of malignancies such as melanoma [78]. Moreover, TNF- $\alpha$ administration induces serious side effects such as septic shock-like condition [79], and thus TNF- $\alpha$ therapy is stringently restricted [80].

GM-CSF is a cytokine produced by immune cells (including T cells, NK cells, macrophages, and mast cells), endothelial cells, and fibroblasts. GM-CSF stimulates white blood cells to grow and stem cells to differentiate to granulocytes and monocytes. Clinical trials have indicated that GM-CSFstimulating factor-secreting cancer immunotherapy in combination with primed lymphocytes and autologous stem cell transplantation in hematologic malignancies was potentially effective against acute myeloid leukemia [81]. In addition, a combination therapy of GM-CSF and IL-2 showed more benefits for melanoma patients [82]. These results indicated that GM-CSF can be used as cytokine therapy for cancer patients.

Cytokines play an important role in the regulation of immune responses. Cytokine therapy, however, rarely results in complete cure for cancer patients due to its indirect antitumor activity. Cytokine administration, on the other hand, has induced toxicities in patients, which limits its potential to be used as cancer therapy. Cytokine therapy may be effective for cancer treatment if the high concentration of cytokines is achieved at tumor sites. In recent years, targeted delivery of cytokines has become possible and indeed antibody-cytokine fusion proteins (immunocytokines) seem to be effective in cancer treatment. Studies in mouse tumor models have shown that the antibody-mediated targeted delivery of IL12 was very effective in cancer treatment $[83,84]$, indicating that immunocytokine therapy may be promising in cancer treatment.

Some cytokines have been shown to cause immunosuppression in cancer patients and therefore have the potential to be used as anticytokine therapy for cancer treatment. There are reports that IL- 6 is an important tumor promoter in early colitis-associated cancer [85]. IL-6, produced by tumorinfiltrating myeloid cells, increases cancer development in the intestinal epithelium and protects cancer cells from apoptotic eradication. Thus, anti-IL-6 therapy may be used in the treatment of colorectal cancer [85].

\section{Antibody Therapy}

Antibody therapy for cancer usually refers to the use of monoclonal antibody (mAb) to bind specifically to cancer cells and directly lead to the death of cancer cells. One of mechanisms is that mAbs kill cancer cells by blocking cancer-specific cell receptors [86]. Also, radioactive materials [87] or anticancer drugs [88] may be conjugated with mAbs to destroy cancer cells after binding of the mAbs to them. Thus, antibody therapy may be very effective for cancer treatment [89].

There are many therapeutic antibodies approved by the FDA for clinical applications in cancer treatment. For instance, three mAbs including epidermal growth factor receptor mAb (cetuximab, Erbitux), vascular endothelial growth factor (VEGF) mAb (bevacizumab, Avastin), and epidermal growth factor receptor mAb (panitumumab, Vectibix) have been approved in the clinical treatment of patients with colorectal cancer [90-92]. Clinical trials also showed that therapy of antiprogrammed death-1 (PD-1) antibody (BMS936558) was safe and effective for treatment of patients with colorectal cancer [93]. Therefore, these antibodies may effectively be used in the treatment for patients with colorectal cancer.

Cetuximab was the first targeted therapy to be used in the treatment of patients with squamous cell carcinoma of the head and neck (SCCHN). Cetuximab therapy has been shown to be clinically beneficial for patients with recurrent/metastatic SCCHN [94].

Bevacizumab was approved in the treatment of lung cancer in the October of 2006 [95]. In antibody-mediated cancer therapy, the mAbs may bind to specific immune cells to regulate antitumor immune responses, indirectly leading to the death of cancer cells. Recent review indicated that anticytotoxic T-lymphocyte antigen 4 (CTLA-4) antibody (ipilimumab) and anti-PD-1 antibody (nivolumab), which block immune-checkpoint pathways, were safe and effective for squamous and nonsquamous non-small-cell lung cancer (NSCLC) [96, 97]. Anti-PD-L1 antibody (BMS-936559) was also found to be safe and effective for the treatment of patients with NSCLC [98].

VEGF is usually overexpressed in patients with renal cell cancer (RCC). Bevacizumab, a mAb against VEGF, was shown to be promising for the treatment of RCC [99]. Clinical trials also discovered that anti-PD-1 antibody (BMS-936558) and anti-PD-L1 antibody (BMS-936559) were found to be safe and effective for the treatment of RCC cancer $[97,98]$.

CTLA-4 binds to the proteins of the B7-family, resulting in the suppression of $\mathrm{T}$ cell functions. Treatment with the CTLA-4 antibodies (ipilimumab and tremelimumab) has been extensively used in metastatic melanoma and showed good benefits with prolonged survival [100]. Clinical trials discovered that anti-PD-1 antibody (BMS-936558) and antiPD-L1 antibody (BMS-936559) were safe and effective for the treatment of patients with melanoma $[97,98]$. Thus, antiCTLA-4, anti-PD-1, and anti-PD-L1 antibodies may effectively be used in the treatment of patients with melanoma.

It is estimated that approximately $20-30 \%$ of patients with breast cancer have overexpressed human epidermal growth factor receptor (HER-2) in breast cancer cells. Overexpression of HER-2 has been shown to be associated with an aggressive tumor phenotype and poor prognosis [101]. Trastuzumab (Herceptin) is a recombinant, humanized, monoclonal antibody that binds to the extracellular domain of the HER-2 protein. Trastuzumab has been approved by the FDA and clinical trials have shown its efficacy for metastatic and early-stage HER-2-positive breast cancer [101, 102].

The human B cell antigen CD20 is expressed at a high level in B-cell non-Hodgkin's lymphoma and thus has been used as a target for antibody therapy for this disease. Clinical trials have shown that the anti-CD20 mAb (rituximab, Rituxan) therapy was effective for patients with B-cell non-Hodgkin's lymphoma and was recently approved by the FDA [103]. 
Studies have shown that therapy with conjugated antibodies is probably more potent in cancer treatment. Radioactive antibodies have been used in imaging and treatment for a long time. Recent developments have shown that a new generation of radioactive antibodies may be effectively used as therapeutic agents for various cancers [104].

Cancer therapy using antibodies conjugated with drug, that is, antibody-drug conjugates (ADC), has been shown to be more effective than unconjugated antibodies alone [105]. The efficacy of ADC therapy depends on the specific binding of mAbs to cancer cells and the cytotoxicity of the conjugated drugs. Therefore, use of antibody-drug conjugates for cancer treatment looks promising.

An antibody may be also fused with cytokines such as IL-2, IL-12, and GM-CSF to make antibody-cytokine fusion proteins. The specific targeting of antibodies fused with cytokines may cause high cytokine concentration in the tumor microenvironment. Therefore, these fusion proteins have the enhanced tumoricidal activity [106] and may activate a secondary antitumor immune response [107].

Bispecific antibodies (bsAbs) [108] or Tandem antibodies (TandAbs) [109] are artificially designed antibodies containing two binding sites, which can bind simultaneously to two different antigens, one on immune system effector cells such as cytotoxic $\mathrm{T}$ cells and the other on tumor cells. Bispecific antibodies thus can cross-link tumor cells and immune cells, leading to the activation of cytotoxic activities of immune effector cells and killing of cancer cells. Due to their strong antitumor activity, bispecific antibodies will become a promising new method for cancer treatment. Recently, attempt was also made to combine bsAbs and multivalent immunocytokines with a tumor cell vaccine, that is, trispecific immunocytokines. Preliminary data have shown that therapy with trispecific immunocytokines is very promising for a new generation of efficient and safe cancer therapeutics that should confer long-lasting antitumor immunity [108].

\section{Vaccination}

Vaccines, known as therapeutic cancer vaccines, are being developed to treat patients with existing cancer and are one of the most active fields in cancer research [110]. Treatment with cancer vaccines, an active immunotherapy for cancer, is a desired method for cancer patients, especially patients with cervical cancer as cervical cancer is caused by viruses, for example, human papillomavirus (HPV). Thus, similar to traditional vaccines against viruses, vaccines are being developed to treat such types of cancer, for example, Cervarix [111] and Gardasil [112].

Sipuleucel-T, which elicited an immune response to prostatic acid phosphatase expressed on prostate cancer cells, was the first FDA-approved therapeutic cancer vaccine for patients with metastatic prostate cancer [113]. Clinical trials showed that the therapeutic telomerase- (TERT-) specific vaccine $\mathrm{Vx}-001$ could induce TERT-reactive $\mathrm{T}$ cells and have a significant overall survival benefit in patients with chemoresistant advanced solid tumors [114]. A therapeutic vaccine, composed of epidermal growth factor (EGF) chemically conjugated to a carrier protein from Neisseria meningitides, induced anti-EGF antibody titters, decreased EGF concentration in plasma, and had survival advantages in vaccinated patients with advanced lung cancer [110]. However, there are currently no therapeutic vaccines available to treat cancers effectively.

It has been reported that the synthetic vaccine of HPV E7 protein-derived peptide antigen and star polymer could be used to treat HPV-related cancers in mice [115]. As an effective therapeutic cancer vaccine candidate, the live attenuated vaccine strain (oncolytic measles virus, MV) engineered with GM-CSF gene has been shown to induce a complete tumor regression and rejected following tumor reengraftment in murine colon adenocarcinoma model [116]. Similarly, GM-CSF surface modified MB49 bladder cancer cells were used as a therapeutic vaccine to inhibit tumor growth significantly and induce resistance to the second injection of MB49 bladder cancer cells but not the other cancer cells [117]. Furthermore, both GM-CSF and TNF$\alpha$-modified RM-1 prostatic cancer cell vaccine, which was superior to single GM-CSF- or TNF- $\alpha$-modified vaccine, significantly prolonged the survival in the mouse model [118]. Thus, the effectiveness of these conjugated cancer vaccines in mouse tumor models provided evidence for future clinical trials.

It has been well known that cancers result from multiple gene mutations, which are diverse among individual cancer patients. Thus, antitumor immune responses induced by tumor-associated antigens are different from one cancer patient to another [119], suggesting that single cancer vaccine may not be effective for all of the cancer patients. Personalized cancer vaccinations may provide a future direction for cancer treatment as therapeutic cancer vaccines. Besides, combination therapy with cancer vaccines and other conventional treatments such as radiation therapy may result in significant tumor regression and serve as a potential treatment regimen for cancer patients [120].

\section{Adoptive Cell Therapy (ACT)}

Conventional cancer treatments including surgery, radiation, and chemotherapy appear to be unsatisfactory. Recent studies have shown that immunotherapy may be a more promising method for cancer treatment [121]. Clinical trials have also demonstrated that adoptive cell therapy, a passive immunotherapy for cancer, was very effective against cancer $[122,123]$.

7.1. Lymphokine-Activated Killer (LAK) Cell Therapy. The development of adoptive cell therapy started with the generation of lymphokine-activated killer (LAK) cells for cancer treatment [124]. LAK cells are generated from peripheral blood mononuclear cells (PBMC) after in vitro culture in the presence of IL-2. PBMC from both healthy donors and cancer patients can be used to generate LAK cells. Also, IL-2 can be used to generate LAK cells in cancer patients in vivo [125]. LAK cells have potential to kill autologous tumor cells and allogeneic cancer cells in vitro. It has been reported that 
LAK cells stimulated by IL- 2 can effectively kill a wide variety of tumors such as colon cancer, pancreatic cancer, adrenal gland cancer, esophageal cancer, renal cancer, and sarcomas in a nonspecific manner, whereas normal peripheral blood lymphocytes could not $[124,126]$. Furthermore, LAK cells can be expanded in vitro without loss of antitumor activity. Thus, LAK cells can be used in the adoptive immunotherapy for cancers. Human LAK cells have been shown to suppress the growth of human lung giant cell cancer in nude mice [127]. Human LAK cells can also induce the complete regression of established human head and neck tumors in nude mice [128]. Targeted human LAK cells had increased uptake into the tumor and suppression of human colon cancer growth in severe combined immunodeficient (SCID) mice [129]. Fluorescent staining indicated that human LAK cells can persist for 7 days in the implanted lung cancer tissue and peripheral blood in SCID mice, leading to significant suppression of human-lung squamous-cell carcinoma cell growth in mice [130]. The results suggested that LAK cells can be used in the immunotherapy for cancer patients.

A common protocol of adoptive LAK cell immunotherapy for cancer patients includes 5 days of IL-2 injections. Next, the cells are collected and activated in vitro in the presence of IL-2 for several days and then the cells are transfused into autologous patients in combination with IL-2 during the next 5 days. However, the clinical efficacy of LAK cell immunotherapy appeared to be relatively low [125] and therefore, LAK cell therapy is not currently used in cancer patients [121].

7.2. Cytokine-Induced Killer (CIK) Cell Therapy. Due to the apparent ineffectiveness of LAK cell therapy for cancer [125], CIK cell therapy has been developed [131]. Generally, CIK cells are generated from human PBMC after in vitro stimulation by multiple factors including IL-2, IL-1, IFN- $\gamma$, and antiCD3 monoclonal antibody $[131,132]$. As compared with LAK cells, CIK cells showed increased antitumor activities both in vitro and in vivo in mouse model [132], suggesting that CIK cell therapy might be more effective for cancer patients.

A case study observed that modified CIK cells could induce partial response in a patient with severe pleural metastasis of collecting duct carcinoma (CDC) of the kidney [133]. A patient with advanced pancreatic adenocarcinoma experienced a longer progression-free survival of $>19$ months, following cytokine-induced killer (CIK) cell therapy, making it the first report showing the beneficial effect of CIK cell immunotherapy in patients [134]. Analysis by searching phase II/III clinical trial databases of CIK cell therapy revealed that CIK cell therapy significantly increased halfyear progression-free survival, one-year progression-free survival, and median time to progression. However, CIK cell therapy did not improve the objective response rate in cancer patients [135]. Similar analysis of CIK therapy of cancer patients observed that out of 426 cancer patients receiving CIK cell therapy, only three patients showed a decrease in tumor volume [136]. Clinical studies concluded that the therapeutic efficacy of CIK cell therapy was not satisfactory [137].
7.3. Dendritic Cell- (DC-) CIK Cell Therapy. Lack of tumor antigen specificities may contribute to the clinical ineffectiveness of CIK cell therapy for cancer. Thus, DC-CIK cells were pursued. After culturing of CIK cells in the presence of antigen-specific pulsed DC, DC-CIK cells showed enhanced lytic activity in vitro against cancer cells such as multiple myeloma cells [138], chronic myelogenous leukemia [139], and osteosarcoma cells [140]. When compared with CIK cells, DC-CIK cells had significantly increased antitumor activities both in vitro and in vivo [141]. DC-CIK cells had also significant inhibitory effects on the growth of A549 lung cancer cells in BALB/c nude mice [142]. These data suggest that DC-CIK cells can be used in the treatment of cancer patients.

Clinical trials of DC-CIK treatment showed increased tumor progression-free survival of patients with advanced non-small-cell lung cancer [143]. Combination of DC-CIK cell therapy with other treatments also increased the overall survival of patients with metastatic non-small-cell lung cancer [144]. Thus, combination of DC-CIK cell therapy with high-dose chemotherapy can increase progression-free and overall survival in patients with metastatic breast cancer [145]. In addition, DC-CIK cells in combination with Chinese herbal medicine Lingdankang composite induced the clearance of minimal residual leukemia in leukemia patients [146]. The results suggested that DC-CIK cell therapy might be effective for cancer patients; however, further studies are required to confirm the effectiveness of DC-CIK cell therapy.

7.4. Tumor-Infiltrating Lymphocyte (TIL) Therapy. Studies have shown that tumor-infiltrating lymphocytes are present in tumor tissues and play an important role in tumor development, regression, and treatment in cancer patients [147-149]. Adoptive cell therapy with TIL in combination with cyclophosphamide and IL-2 cured advanced hepatic metastases and pulmonary metastases in mice [150]. The data suggested that TILs can be used in effective cancer treatment.

It has been documented that tumor-reactive TILs can easily be generated from patients with metastatic melanoma for adoptive cell therapy $[151,152]$. Tumor reactive TILs were also obtained from patients with renal cell carcinoma [153], breast cancer [154], and oral squamous cell carcinoma (OSCC) [155]. Similarly, TILs can also be generated from patients with ovarian carcinoma and can be expanded up to 8,000-fold for clinical application by adoptive immunotherapy [156].

Clinical trials have demonstrated that adoptive cell therapy with antitumor TILs in lymphodepleted hosts induced tumor regression in $50 \%$ to $70 \%$ of treated patients with metastatic melanoma refractory to standard therapies [123], suggesting that adoptive cell therapy with antitumor TIL was an effective method for cancer treatment. Further studies demonstrated that the persistence of multiple tumor-reactive cell clones might be responsible for tumor regression in responding patients receiving TIL therapy [157, 158]. In addition, the telomere length of transferred lymphocytes was correlated with clinical responses in metastatic melanoma patients after adoptive cell therapy with antitumor TILs [159]. These results indicated that young TILs with long telomeres 
may be more potent in the induction of tumor regression for adoptive cell therapy [160].

TILs were also generated from 113 out of 131 patients with non-small-cell lung carcinoma. Clinical trials have demonstrated that adoptive immunotherapy with TILs and IL-2 was safe to use for the treatment of patients with nonsmall-cell lung carcinoma and improved at least three-year survival for patients [161]. Thus, adoptive cell therapy with antitumor TILs may also be used in the effective treatment of patients with the other cancers.

7.5. Genetically Engineered T Cell Therapy. It is impossible to obtain tumor-reactive TILs from all of the cancer patients for adoptive cell therapy. There are reports indicating that antitumor activity was detected in TIL samples of $81 \%$ of patients with metastatic melanoma [151], which was one of the best situations for generating tumor-reactive TILs. From patients with gastrointestinal (GI) cancers, however, less than $3 \%$ of expanded bulk TILs were tumor-reactive [162]. Thus, there is need to employ genetic methods to modify $\mathrm{T}$ cells to increase antitumor activities for adoptive cell therapy of cancer patients.

Normally, viral vectors carrying genes coding $\mathrm{T}$ cell receptors (TCRs) specific to tumor antigens or chimeric antigen receptors (CARs) are genetically introduced into PBMC or tumor-infiltrating lymphocytes. At present, there are two types of genetically engineered $\mathrm{T}$ cells available for adoptive cell therapy for cancers, TCR gene- and CAR gene-modified T cells. Genetically engineered T lymphocytes have high avidity and tumor reactivity. For example, genetically engineered $\mathrm{T}$ lymphocytes are highly reactive to gp100 melanoma tumor antigen [163]. Antiepidermal growth factor receptor variant III (EGFRvIII) CAR-engineered T cells were generated to have antitumor reactivity against antigen-expressing glioma target cells [164].

A clinical trial of genetically engineered $\mathrm{T}$ lymphocytes reactive to MART-1 and gp100 for adoptive cell transfer showed effectiveness against tumor progression in metastatic melanoma patients [165]. Adoptive cell therapy with $\mathrm{T}$ cell receptor- (TCR-) transduced T cells against NY-ESO-1 induced tumor regression in patients with synovial cell sarcoma and metastatic melanoma [166].

$\mathrm{T}$ cells engineered with a CAR which binds to CD19 on chronic lymphocytic leukemia (CLL) cells through an antibody-derived domain triggered $\mathrm{T}$ cell activation through $\mathrm{CD} 3 \zeta$ upon tumor cell engagement [167]. Infusion of CD19specific CAR-transduced mouse $\mathrm{T}$ cells alone induced longterm $B$ cell eradication in mouse model of $B$ cell acute lymphoblastic leukemia (B-ALL) and primary human preB-cell acute lymphoblastic leukemia $[168,169]$. Therefore, adoptive cell therapy using genetically engineered $\mathrm{T}$ cells with antitumor activity seems to be effective in cancer treatment.

\section{Prospects in Cancer Immunotherapy}

Recent developments and clinical trials have shown that immunotherapy may be promising and effective for patients with cancers $[102,103,123,166,169]$. Due to the multistep nature of cancer development $[24,25]$, numerous genetic clones of cancer cells [28], and tumor antigen heterogeneities [119], effective therapies for cancer patients may require highly personalized treatments. Thus, cancer vaccines may be used in the prevention and treatment of patients with virus-induced cancers such as $\mathrm{HPV}$-induced cervical cancer $[111,112]$.

Merkel cell polyomavirus (MCV) has been shown to be directly linked to human cancer, Merkel cell carcinoma (MCC) [170]. MCV viral oncoproteins, expressed in the majority of MCC tumors, played an important role in tumor development [171]. Besides, an intense T cell infiltration was found to be associated with the presence of MCV DNA in MCC and tumor-infiltrating T cell counts were connected with good survival [172]. Therefore, MCV viral oncoproteins may be a good candidate for cancer vaccine development for MCC treatment.

Infection with Hepatitis B virus (HBV) and Hepatitis C (HCV) virus appeared to be one of the factors contributing to hepatocellular carcinoma (HCC) development [173]. It has been reported that chronic $\mathrm{HBV}$ infection is responsible for HCC development in $>50 \%$ of cases and viral proteins may play a critical role in liver cancer [174]. Thus, HBV viral proteins may be used for the development of preventive vaccines for liver cancers.

An association between JC virus (JCV) and colorectal cancers (CRC) is known [175, 176]. JCV encodes a gene expressing T-antigen, which is detected in the majority of CRC patients with positive family history [177]. These results indicate that $\mathrm{T}$-antigen may be used in the development of cancer vaccines for CRC.

The Epstein Barr virus (EBV) has been shown to cause different types of lymphoma and nasopharyngeal cancer [178]. EBV encoding viral proteins such as LMP1 may serve as important targets for cancer vaccines [179-181]. Studies have shown that EBV vaccines appear to be most promising for the prevention and treatment of EBV-related cancers [182].

Other viruses such as human $\mathrm{T}$ cell lymphoma virus-1 (HTLV-1) also play a role in cancer development. HTLV-1 is responsible for the development of adult $\mathrm{T}$ cell leukemia (ATL) [183]. HTLV-1 viral proteins may be used in the development of cancer vaccines for ATL $[184,185]$. Mouse model studies have reported that a live attenuated measles vaccine virus $\mathrm{Hu}-191$ strain (MV) could effectively suppress the growth of mouse lung carcinoma, suggesting that this approach may be promising in the treatment of human advanced lung cancer [186].

Clinical trials have demonstrated that adoptive cell therapy with antitumor TILs could effectively induce tumor regression in approximately $50-75 \%$ of patients with metastatic melanoma $[122,123]$. Thus, adoptive cell transfer therapy with antitumor TILs may be extended to treat patients with other forms of cancers such as breast, renal, and lung cancers. Recent studies have shown that TILs generated from liver and lung metastases from patients with GI cancers had similar proportions of $\mathrm{CD}^{+} \mathrm{T}$ cells, $\mathrm{T}$ cell differentiation stage, expression of costimulatory molecules, and expansion scale for clinical application to those derived from patients with metastatic melanoma [162]. Different from TILs from metastatic melanoma, however, TILs from 
GI cancers usually did not maintain the antitumor activity after large-scale expansion and less than $3 \%$ of expanded bulk TILs from GI cancers were tumor-reactive. Thus, the obstacle for adoptive transfer therapy with TILs for patients with GI cancers was the loss of the antitumor reactivity of TILs after expansion. Use of selected and enriched tumorreactive $\mathrm{T}$ cells instead of bulk TILs for expansion may keep the antitumor reactivity of expanded TILs [162]. It is expected that adoptive cell therapy with antitumor TILs can be successfully used in the treatment of patients with various forms of cancers.

Genetically engineered $\mathrm{T}$ cells with $\mathrm{T}$ cell receptor genes and chimeric antigen receptors have been shown to be effective in the treatment of cancer patients $[165,166,169]$. Thus far, limited genetically engineered $\mathrm{T}$ cells, which are reactive to only several tumor antigens (such as gp100, MART-1 and NY-ESO-1) and one CAR binding to CD19, are available for cancer treatment $[165,166,169]$. Since more than 2,000 tumor antigens have been identified from various cancers [187], it is anticipated that more genetically engineered $\mathrm{T}$ cells will be used in the effective treatment of cancer patients in the near future.

Combination therapies usually are the most promising and effective in the treatment of human diseases [188]. For example, combination therapy of DC vaccine and IL-2 can induce antigen-specific immune response, reduce inhibitory immunity, and stabilize diseases in patients with renal cell carcinoma and breast cancer [189]. DC-CIK immunotherapy in combination with high-dose chemotherapy can improve progression-free and overall survival in patients with metastatic breast cancer [145]. DC-CIK immunotherapy in combination with cryotherapy or chemotherapy was proved to the best treatment for patients with metastatic NSCLC [144]. Adoptive cell therapy with antitumor TILs in combination with nonmyeloablative chemotherapy and total body irradiation can induce tumor regression in $72 \%$ of patients with metastatic melanoma, whereas TIL adoptive immunotherapy in combination with nonmyeloablative chemotherapy can induce tumor regression in only $52 \%$ of treated patients [123]. Therefore, combination therapies will be superior choices for cancer immunotherapy in the future.

\section{Conflict of Interests}

The author declares that there is no conflict of interests regarding the publication of this paper.

\section{Acknowledgment}

This work was supported by "Taishan Scholar" special fund (no. 109, 2012) from Shandong Government, China.

\section{References}

[1] D. Hanahan and R. A. Weinberg, "Hallmarks of Cancer: the next generation," Cell, vol. 144, no. 5, pp. 646-674, 2011.

[2] A. C. Society, Cancer Facts and Figures 2013, American Cancer Society, Atlanta, Ga, USA, 2013.
[3] R. S. . Katikireddi and S. N. R. S. Setty, "The incidence of common Cancers in south indian region-a hospital based cross sectional study - research article," International Journal of Current Research and Review, vol. 5, p. 37, 2013.

[4] A. Rosta, "Diabetes and risk of tumors: oncologic considerations," Orvosi Hetilap, vol. 152, no. 29, pp. 1144-1155, 2011.

[5] A. Recht and M. J. Houlihan, "Conservative surgery without radiotherapy in the treatment of patients with early-stage invasive breast Cancer: a review," Annals of Surgery, vol. 222, no. 1, pp. 9-18, 1995.

[6] G. Lezoche et al., "Treatment of rectal Cancer by transanal endoscopic microsurgery: review of the literature," Minerva Chirurgica, vol. 68, p. 1, 2013.

[7] C. M. Mansfield, L. Krishnan, L. T. Komarnicky, K. M. Ayyangar, and C. A. Kramer, "A review of the role of radiation therapy in the treatment of patients with breast Cancer," Seminars in Oncology, vol. 18, no. 6, pp. 525-535, 1991.

[8] A. Munshi, J. P. Agarwal, and K. C. Pandey, "Cancer patients with cardiac pacemakers needing radiation treatment: a systematic review," Journal of Cancer Research and Therapeutics, vol. 9, p. 193, 2013.

[9] M. Johnson, "Chemotherapy treatment decision making by professionals and older patients with Cancer: a narrative review of the literature," European Journal of Cancer Care, vol. 21, no. 1, pp. 3-9, 2012.

[10] J. Goffin, C. Lacchetti, P. M. Ellis, Y. C. Ung, and W. K. Evans, "First-line systemic chemotherapy in the treatment of advanced non-small cell lung Cancer: a systematic review," Journal of Thoracic Oncology, vol. 5, no. 2, pp. 260-274, 2010.

[11] D. Prezioso, G. Piccirillo, R. Galasso, V. Altieri, V. Mirone, and T. Lotti, "Gynecomastia due to hormone therapy for advanced prostate Cancer: a report of ten surgically treated cases and a review of treatment options," Tumori, vol. 90, no. 4, pp. 410-415, 2004.

[12] A. M. Manganoni, C. Zane, L. Pavoni, C. Farisoglio, E. Sereni, and P. Calzavara-Pinton, "Cutaneous melanoma in patients in treatment with biological therapy: review of the literature and case report," Dermatology Online Journal, vol. 17, no. 8, p. 12, 2011.

[13] J. M. Balwit, P. Kalinski, V. K. Sondak et al., "Review of the 25th annual scientific meeting of the International Society for Biological Therapy of Cancer," Journal of Translational Medicine, vol. 9, p. 60, 2011.

[14] M. Kudo, "Targeted therapy for liver Cancer: updated review in 2012," Current Cancer Drug Targets, vol. 12, p. 1062, 2012.

[15] C. Coppin, C. Kollmannsberger, L. Le, F. Porzsolt, and T. J. Wilt, "Targeted therapy for advanced renal cell Cancer (RCC): a Cochrane systematic review of published randomised trials," BJU International, vol. 108, no. 10, pp. 1556-1563, 2011.

[16] G. A. Silvestri and M. P. Rivera, "Targeted therapy for the treatment of advanced non-small cell lung Cancer: a review of the epidermal growth factor receptor antagonists," Chest, vol. 128, no. 6, pp. 3975-3984, 2005.

[17] A. Jemal, R. Siegel, E. Ward et al., "Cancer statistics, 2008," CA: Cancer Journal for Clinicians, vol. 58, no. 2, pp. 71-96, 2008.

[18] D. Lutz, "Immunotherapy of Cancer: a critical review," International Journal of Clinical Pharmacology Therapy and Toxicology, vol. 21, no. 3, pp. 118-129, 1983.

[19] S. A. Rosenberg, "Clinical immunotherapy studies in the Surgery Branch of the U.S. National Cancer Institute: brief review," Cancer Treatment Reviews, vol. 16, pp. 115-121, 1989. 
[20] A. I. Riker, S. Radfar, S. Liu, Y. Wang, and H. T. Khong, "Immunotherapy of melanoma: a critical review of current concepts and future strategies," Expert Opinion on Biological Therapy, vol. 7, no. 3, pp. 345-358, 2007.

[21] R. D. Hall, J. E. Gray, and A. A. Chiappori, "Beyond the standard of care: a review of novel immunotherapy trials for the treatment of lung Cancer," Cancer Control, vol. 20, p. 22, 2013.

[22] E. Farber, "The multistep nature of Cancer development," Cancer Research, vol. 44, no. 10, pp. 4217-4223, 1984.

[23] S. Sukumar, "An experimental analysis of Cancer: role of ras oncogenes in multistep carcinogenesis," Cancer Cells, vol. 2, no. 7, pp. 199-204, 1990.

[24] A. Karakosta, C. Golias, A. Charalabopoulos, D. Peschos, A. Batistatou, and K. Charalabopoulos, "Genetic models of human Cancer as a multistep process. Paradigm models of colorectal Cancer, breast Cancer, and chronic myelogenous and acute lymphoblastic leukaemia," Journal of Experimental and Clinical Cancer Research, vol. 24, no. 4, pp. 505-514, 2005.

[25] H. Ballentine Carter, S. Piantadosi, and J. T. Isaacs, "Clinical evidence for and implications of the multistep development of prostate Cancer," Journal of Urology, vol. 143, no. 4, pp. 742-746, 1990.

[26] P. C. Nowell, “The clonal evolution of tumor cell populations. Acquired genetic lability permits stepwise selection of variant sublines and underlies tumor progression," Science, vol. 194, no. 4260, pp. 23-28, 1976.

[27] M. Greaves and C. C. Maley, "Clonal evolution in Cancer," Nature, vol. 481, no. 7381, pp. 306-313, 2012.

[28] M. Jan and R. Majeti, "Clonal evolution of acute leukemia genomes," Oncogene, vol. 32, p. 135, 2012.

[29] B. Parkin et al., "Clonal evolution and devolution after chemotherapy in adult acute myelogenous leukemia," Blood, vol. 121, p. 369, 2013.

[30] M. Castellarin, K. Milne, T. Zeng et al., "Clonal evolution of high-grade serous ovarian carcinoma from primary to recurrent disease," The Journal of Pathology, vol. 229, p. 515, 2013.

[31] H. Clevers, "The Cancer stem cell: premises, promises and challenges," Nature Medicine, vol. 17, no. 3, pp. 313-319, 2011.

[32] P. S. Rudland, E. J. Ormerod, and F. C. Paterson, "Stem cells in rat mammary development and Cancer: a review," Journal of the Royal Society of Medicine, vol. 73, no. 6, pp. 437-442, 1980.

[33] P. Selby, J. P. Bizzari, and R. N. Buick, "Therapeutic implications of a stem cell model for human breast Cancer: a hypothesis," Cancer Treatment Reports, vol. 67, no. 7-8, pp. 659-663, 1983.

[34] D. Bonnet and J. E. Dick, "Human acute myeloid leukemia is organized as a hierarchy that originates from a primitive hematopoietic cell," Nature Medicine, vol. 3, no. 7, pp. 730-737, 1997.

[35] P. B. Dirks, "Brain tumor stem cells: the Cancer stem cell hypothesis writ large," Molecular Oncology, vol. 4, no. 5, pp. 420430, 2010.

[36] D. H. Kumar and M. K. Kutty, "Review of stem cell deregulation and breast Cancer: an emerging hypothesis," Indian Journal of Pathology \& Microbiology, vol. 55, p. 147, 2012.

[37] S. Susman, C. Tomuleasa, O. Soritau et al., "The colorectal Cancer stem-like cell hypothesis: a pathologist's point of view," Journal of the Balkan Union of Oncology, vol. 17, p. 230, 2012.

[38] M. Rahman, L. Deleyrolle, V. Vedam-Mai, H. Azari, M. AbdEl-Barr, and B. A. Reynolds, "The Cancer stem cell hypothesis: failures and pitfalls," Neurosurgery, vol. 68, no. 2, pp. 531-545, 2011.
[39] J. D. O’Flaherty, M. Barr, D. Fennell et al., “The Cancer stemcell hypothesis: its emerging role in lung Cancer biology and its relevance for future therapy," Journal of Thoracic Oncology, vol. 7, p. 1880, 2012.

[40] C. Samardzija, M. Quinn, J. K. Findlay, and N. Ahmed, "Attributes of Oct4 in stem cell biology: perspectives on Cancer stem cells of the ovary," Journal of Ovarian Research, vol. 5, p. 37, 2012.

[41] N. J. Maitland and A. Collins, "A tumour stem cell hypothesis for the origins of prostate Cancer," BJU International, vol. 96, no. 9, pp. 1219-1223, 2005.

[42] A. Rocco, D. Compare, and G. Nardone, "Cancer stem cell hypothesis and gastric carcinogenesis: experimental evidence and unsolved questions," World Journal of Gastrointestinal Oncology, vol. 4, p. 54, 2012.

[43] A. Morotti, C. Panuzzo, C. Fava, and G. Saglio, "Kinaseinhibitor-insensitive Cancer stem cells in chronic myeloid leukemia," Expert Opinion on Biological Therapy, vol. 14, no. 3, pp. 287-299, 2014.

[44] O. Shakhova and L. Sommer, "Testing the Cancer stem cell hypothesis in melanoma: the clinics will tell," Cancer Letters, vol. 338, p. 74, 2013.

[45] M. A. Gonzalez-Moles, C. Scully, I. Ruiz-Avila, and J. J. PlazaCampillo, "The Cancer stem cell hypothesis applied to oral carcinoma," Oral Oncology, vol. 49, p. 738, 2013.

[46] D. Lilic, "Immune response to infection," Anaesthesia and Intensive Care Medicine, vol. 10, no. 5, pp. 218-220, 2009.

[47] R. Doll and L. Kinlen, "Immunosurveillance and Cancer: epidemiological evidence," British Medical Journal, vol. 4, no. 732, pp. 420-422, 1970.

[48] G. P. Dunn, A. T. Bruce, H. Ikeda, L. J. Old, and R. D. Schreiber, "Cancer immunoediting: from immunosurveillance to tumor escape," Nature Immunology, vol. 3, no. 11, pp. 991-998, 2002.

[49] J. Galon, H. K. Angell, D. Bedognetti, and F. M. Marincola, "The continuum of Cancer immunosurveillance: prognostic, predictive, and mechanistic signatures," Immunity, vol. 39, p. 11, 2013.

[50] C. Y. Slaney, J. Rautela, and B. S. Parker, "The emerging role of immunosurveillance in dictating metastatic spread in Breast Cancer," Cancer Research, vol. 73, p. 5852, 2013.

[51] B. Lakshmi Narendra, K. Eshvendar Reddy, S. Shantikumar, and S. Ramakrishna, "Immune system: a double-edged sword in Cancer," Inflammation Research, vol. 62, p. 823, 2013.

[52] V. C. Goswitz and Z. P. Sawicki, "Cancer therapy based on a mechanism of action for controlling the immune system and the resulting patent portfolio," Recent Patents on Endocrine, Metabolic \& Immune Drug Discovery, vol. 7, p. 1, 2013.

[53] Y. Liu and G. Zeng, "Cancer and innate immune system interactions: translational potentials for Cancer immunotherapy," Journal of Immunotherapy, vol. 35, no. 4, pp. 299-308, 2012.

[54] S. Rangwala and K. Y. Tsai, "Roles of the immune system in skin Cancer," British Journal of Dermatology, vol. 165, no. 5, pp. 953965, 2011.

[55] P. Hwu, "Treating Cancer by targeting the immune system," The New England Journal of Medicine, vol. 363, no. 8, pp. 779-781, 2010.

[56] A. Hamaï, H. Benlalam, F. Meslin et al., "Immune surveillance of human Cancer: if the cytotoxic T-lymphocytes play the music, does the tumoral system call the tune?" Tissue Antigens, vol. 75, no. 1, pp. 1-8, 2010. 
[57] L. Von Boehmer, A. Draenert, W. Jungraithmayr et al., "Immunosuppression and lung Cancer of donor origin after bilateral lung transplantation," Lung Cancer, vol. 76, no. 1, pp. $118-122,2012$.

[58] P. A. Dugue, M. Rebolj, P. Garred, and E. Lynge, "Immunosuppression and risk of cervical Cancer," Expert Review of AntiCancer Therapy, vol. 13, p. 29, 2013.

[59] A. B. Frey and N. Monu, "Effector-phase tolerance: another mechanism of how Cancer escapes antitumor immune response," Journal of Leukocyte Biology, vol. 79, no. 4, pp. 652-662, 2006.

[60] S. Feyler, P. J. Selby, and G. Cook, "Regulating the regulators in Cancer-immunosuppression in multiple myeloma (MM)," Blood Reviews, vol. 27, p. 155, 2013.

[61] M. Terme et al., "Cancer-induced immunosuppression: IL-18elicited immunoablative NK cells," Cancer Research, vol. 72, p. 2757, 2012.

[62] M. Terme, E. Ullrich, L. Aymeric et al., "IL-18 induces PD-1dependent immunosuppression in Cancer," Cancer Research, vol. 71, p. 5393, 2011.

[63] J. Cheng, L. Li, Y. Liu, Z. Wang, X. Zhu, and X. Bai, "Interleukinlalpha induces immunosuppression by mesenchymal stem cells promoting the growth of prostate Cancer cells," Molecular Medicine Reports, vol. 6, p. 955, 2012.

[64] J. F. Navarro-González and C. Mora-Fernández, "The role of inflammatory cytokines in diabetic nephropathy," Journal of the American Society of Nephrology, vol. 19, no. 3, pp. 433-442, 2008.

[65] J. H. Lee, H. Torisu-Itakura, A. J. Cochran et al., "Quantitative analysis of melanoma-induced cytokine-mediated immunosuppression in melanoma sentinel nodes," Clinical Cancer Research, vol. 11, no. 1, pp. 107-112, 2005.

[66] D. Lutz, "Interferon-alpha therapy in chronic myeloid leukemia," Wien Med Wochenschr, vol. 143, p. 416, 1993.

[67] K. V. Bogdanov, O. I. Frolova, O. V. Marinetz, Y. S. Ogorodnikova, B. V. Afanasiev, and A. Y. Zaritsky, "The efficacy of interferon- $\alpha$ therapy in $\mathrm{Ph}$-positive chronic myeloid leukemia," Voprosy Onkologii, vol. 49, no. 2, pp. 189-192, 2003.

[68] P. Von Wussow, B. Block, F. Hartmann, and H. Deicher, "Intralesional interferon-alpha therapy in advanced malignant melanoma," Cancer, vol. 61, no. 6, pp. 1071-1074, 1988.

[69] S. Mocellin, S. Pasquali, C. R. Rossi, and D. Nitti, "Interferon alpha adjuvant therapy in patients with high-risk melanoma: a systematic review and meta-analysis," Journal of the National Cancer Institute, vol. 102, no. 7, pp. 493-501, 2010.

[70] E. Minutilli and C. Feliciani, "Adjuvant therapy for resected stage III melanoma patients: high-dose interferon-alpha versus ipilimumab combined with kinases inhibitors," Tumori, vol. 98, p. 185, 2012.

[71] P. Liu, C. Zhang, J. Chen et al., "Combinational therapy of interferon- $\alpha$ and chemotherapy normalizes tumor vasculature by regulating pericytes including the novel marker rgs5 in melanoma," Journal of Immunotherapy, vol. 34, no. 3, pp. 320326, 2011.

[72] R. E. Royal, S. M. Steinberg, R. S. Krouse et al., "Correlates of response to IL-2 therapy in patients treated for metastatic renal Cancer and melanoma," Cancer Journal from Scientific American, vol. 2, no. 2, pp. 91-98, 1996.

[73] E. G. Elias, J. L. Zapas, S. L. Beam, and S. D. Brown, "GMCSF and IL-2 combination as adjuvant therapy in cutaneous melanoma: early results of a phase II clinical trial," Oncology, vol. 19, no. 4, pp. 15-18, 2005.
[74] S. Fateh, T. D. Schell, R. Gingrich, R. I. Neves, and J. J. Drabick, "Unsuccessful high dose IL-2 therapy followed immediately by near continuous low dose temozolomide can result in rapid durable complete and near-complete remissions in metastatic melanoma," Cancer Biology and Therapy, vol. 10, no. 11, pp. 10911097, 2010.

[75] K. Haranaka, "Tumor necrosis factor: how to improve the antitumor activity and decrease accompanying side effects for therapeutic application," Journal of Biological Response Modifiers, vol. 7, no. 6, pp. 525-534, 1988.

[76] R. S. Sidhu and A. P. Bollon, "Tumor necrosis factor activities and Cancer therapy-a perspective," Pharmacology and Therapeutics, vol. 57, no. 1, pp. 79-128, 1993.

[77] S. Mocellin, C. R. Rossi, P. Pilati, and D. Nitti, "Tumor necrosis factor, Cancer and antiCancer therapy," Cytokine and Growth Factor Reviews, vol. 16, no. 1, pp. 35-53, 2005.

[78] G. Kouklakis, E. I. Efremidou, M. Pitiakoudis, N. Liratzopoulos, and A. Polychronidis, "Development of primary malignant melanoma during treatment with a TNF-alpha antagonist for severe Crohn's disease: a case report and review of the hypothetical association between TNF-alpha blockers and Cancer," Drug Design, Development and Therapy, vol. 7, p. 195, 2013.

[79] P. Sorkin, S. Abu-Abid, D. Lev et al., "Systemic leakage and side effects of tumor necrosis factor $\alpha$ administered via isolated limb perfusion can be manipulated by flow rate adjustment," Archives of Surgery, vol. 130, no. 10, pp. 1079-1084, 1995.

[80] W. Cai, Z. J. Kerner, H. Hong, and J. Sun, "Targeted Cancer therapy with tumor necrosis factor-Alpha," Biochem Insights, vol. 15, 2008.

[81] I. M. Borrello, H. I. Levitsky, W. Stock et al., "Granulocytemacrophage colony-stimulating factor (GM-CSF)-secreting cellular immunotherapy in combination with autologous stem cell transplantation (ASCT) as postremission therapy for acute myeloid leukemia (AML)," Blood, vol. 114, no. 9, pp. 1736-1745, 2009.

[82] E. G. Elias, J. L. Zapas, E. C. McCarron, S. L. Beam, J. H. Hasskamp, and W. J. Culpepper, "Sequential administration of GMCSF (sargramostim) and IL- $2 \pm$ autologous vaccine as adjuvant therapy in cutaneous melanoma: an interim report of a phase II clinical trial," Cancer Biotherapy and Radiopharmaceuticals, vol. 23, no. 3, pp. 285-291, 2008.

[83] H. Kim, W. Gao, and M. Ho, "Novel immunocytokine IL12-SS1 (Fv) inhibits mesothelioma tumor growth in nude mice," PloS One, vol. 8, Article ID e81919, 2013.

[84] T. Hemmerle and D. Neri, "The antibody-based targeted delivery of interleukin- 4 and 12 to the tumor neovasculature eradicates tumors in three mouse models of Cancer," International Journal of Cancer. Journal International Du Cancer, 2013.

[85] K. Wang, S. I. Grivennikov, and M. Karin, "Implications of anti-cytokine therapy in colorectal Cancer and autoimmune diseases," Annals of the Rheumatic Diseases, vol. 72, supplement 2, p. iil00, 2013.

[86] S. Nishina, K. Yoshida, and K. Nakagawa, "Mechanisms of antibody-based therapy against solid tumors," Japanese Journal of Clinical Medicine, vol. 70, p. 2093, 2012.

[87] E. Vegt, M. D. Jong, J. F. M. Wetzels et al., "Renal toxicity of radiolabeled peptides and antibody fragments: mechanisms, impact on radionuclide therapy, and strategies for prevention," Journal of Nuclear Medicine, vol. 51, no. 7, pp. 1049-1058, 2010.

[88] Q. Lai et al., "Multimodal treatment for acute antibodymediated renal transplant rejection: successful rescue therapy 
with combined plasmapheresis, photopheresis and intravenous immunoglobulin," Giornale Italiano Di Nefrologia, vol. 29, supplement 54, p. S31, 2012.

[89] S. Panowksi, S. Bhakta, H. Raab, P. Polakis, and J. R. Junutula, "Site-specific antibody drug conjugates for Cancer therapy," MAbs, vol. 6, p. 34, 2014.

[90] C. R. Garrett and C. Eng, "Cetuximab in the treatment of patients with colorectal Cancer," Expert Opinion on Biological Therapy, vol. 11, no. 7, pp. 937-949, 2011.

[91] R. Islam, P. H. Chyou, and J. K. Burmester, "Modeling efficacy of bevacizumab treatment for metastatic colon Cancer," Journal of Cancer, vol. 4, p. 330, 2013.

[92] K. J. Williams and A. C. Lockhart, "Targeting colorectal Cancer with anti-epidermal growth factor receptor antibodies: focus on panitumumab," OncoTargets and Therapy, vol. 2, p. 161, 2009.

[93] E. J. Lipson, W. H. Sharfman, C. G. Drake et al., "Durable Cancer regression off-treatment and effective reinduction therapy with an anti-PD-1 antibody," Clinical Cancer Research, vol. 19, p. 462, 2013.

[94] C. J. Langer, "Targeted therapy in head and neck Cancer: state of the art 2007 and review of clinical applications," Cancer, vol. 112, no. 12, pp. 2635-2645, 2008.

[95] C. Clément-Duchêne and H. Wakelee, "Antiangiogenic agents and vascular disrupting agents for the treatment of lung Cancer: a review," Journal of Thoracic Oncology, vol. 5, no. 1, pp. 129-139, 2010.

[96] C. Zielinski, S. Knapp, C. Mascaux, and F. Hirsch, "Rationale for targeting the immune system through checkpoint molecule blockade in the treatment of non-small-cell lung Cancer," Annals of Oncology, vol. 24, p. 1170, 2013.

[97] S. L. Topalian, F. S. Hodi, J. R. Brahmer et al., "Safety, activity, and immune correlates of anti-PD-1 antibody in Cancer," The New England Journal of Medicine, vol. 366, p. 2443, 2012.

[98] J. R. Brahmer, S. S. Tykodi, L. Q. M. Chow et al., "Safety and activity of anti-PD-L1 antibody in patients with advanced Cancer," The New England Journal of Medicine, vol. 366, p. 2455, 2012.

[99] E. Oosterwijk, O. C. Boerman, W. J. C. Oyen, L. J. Old, and P. F. A. Mulders, "Antibody therapy in renal cell carcinoma," World Journal of Urology, vol. 26, no. 2, pp. 141-146, 2008.

[100] A. M. M. Eggermont, A. Testori, M. Maio, and C. Robert, "AntiCTLA-4 antibody adjuvant therapy in melanoma," Seminars in Oncology, vol. 37, no. 5, pp. 455-459, 2010.

[101] G. G. Steger, J. Abrahámová, F. Bacanu et al., "Current standards in the treatment of metastatic breast Cancer with focus on Lapatinib: a review by a Central European Consensus Panel," Wiener Klinische Wochenschrift, vol. 122, no. 11-12, pp. 368-379, 2010.

[102] K. P. Garnock-Jones, G. M. Keating, and L. J. Scott, "Trastuzumab: a review of its use as adjuvant treatment in human epidermal growth factor receptor 2 (HER2)-positive early breast Cancer," Drugs, vol. 70, p. 215, 2010.

[103] P. Z. Teo, P. J. Utz, and J. A. Mollick, "Using the allergic immune system to target Cancer: activity of IgE antibodies specific for human CD20 and MUC1," Cancer Immunology and Immunotherapy, vol. 61, p. 2295, 2012.

[104] D. M. Goldenberg and R. M. Sharkey, "Radioactive antibodies: a historical review of selective targeting and treatment of Cancer," Hospital Practice, vol. 38, p. 82, 1995.

[105] E. L. Sievers and P. D. Senter, "Antibody-drug conjugates in Cancer therapy," Annual Review of Medicine, vol. 64, p. 15, 2013.
[106] T. List and D. Neri, "Immunocytokines: a review of molecules in clinical development for Cancer therapy," Clinical Pharmacology, vol. 5, p. 29, 2013.

[107] E. Ortiz-Sánchez, G. Helguera, T. R. Daniels, and M. L. Penichet, "Antibody-cytokine fusion proteins: applications in Cancer therapy," Expert Opinion on Biological Therapy, vol. 8, no. 7, p. 1037, 2008.

[108] P. Fournier and V. Schirrmacher, "Bispecific antibodies and trispecific immunocytokines for targeting the immune system against Cancer: preparing for the future," BioDrugs, vol. 27, p. 35, 2013.

[109] F. McAleese and M. Eser, "RECRUIT-TandAbs: harnessing the immune system to kill Cancer cells," Future Oncology, vol. 8, p. $687,2012$.

[110] G. Gonzalez, T. Crombet, and A. Lage, "Chronic vaccination with a therapeutic egf-based Cancer vaccine: a review of patients receiving long lasting treatment," Current Cancer Drug Targets, vol. 11, no. 1, pp. 103-110, 2011.

[111] E. J. Crosbie and H. C. Kitchener, "Cervarix-a bivalent L1 virus-like particle vaccine for prevention of human papillomavirus type 16- and 18-associated cervical Cancer," Expert Opinion on Biological Therapy, vol. 7, no. 3, pp. 391-396, 2007.

[112] E. Hanna and G. Bachmann, "HPV vaccination with Gardasil: a breakthrough in women's health," Expert Opinion on Biological Therapy, vol. 6, no. 11, pp. 1223-1227, 2006.

[113] M. A. Cheever and C. S. Higano, "PROVENGE (sipuleucel-T) in prostate Cancer: the first FDA-approved therapeutic Cancer vaccine," Clinical Cancer Research, vol. 17, no. 11, pp. 3520-3526, 2011.

[114] E.-K. Vetsika, G. Konsolakis, D. Aggouraki et al., "Immunological responses in Cancer patients after vaccination with the therapeutic telomerase-specific vaccine Vx-001," Cancer Immunology, Immunotherapy, vol. 61, no. 2, pp. 157-168, 2012.

[115] T. Y. Liu, W. M. Hussein, Z. Jia et al., "Self-adjuvanting polymerpeptide conjugates as therapeutic vaccine candidates against cervical Cancer," Biomacromolecules, vol. 14, p. 2798, 2013.

[116] C. Grossardt, C. E. Engeland, S. Bossow et al., "Granulocytemacrophage colony-stimulating factor-armed oncolytic measles virus is an effective therapeutic Cancer vaccine," Human Gene Therapy, vol. 24, p. 644, 2013.

[117] X. Zhang, X. Shi, J. Li et al., "A novel therapeutic vaccine of mouse GM-CSF surface modified MB49 cells against metastatic bladder Cancer," Journal of Urology, vol. 187, no. 3, pp. 1071-1079, 2012.

[118] W. Yin, Q. He, Z. Hu et al., "A novel therapeutic of GMCSF/TNFalpha surface-modified RM-1 cells against the orthotopic prostatic Cancer," Vaccine, vol. 28, no. 31, pp. 4937-4944, 2010.

[119] M. Noguchi, T. Sasada, and K. Itoh, "Personalized peptide vaccination: a new approach for advanced Cancer as therapeutic Cancer vaccine," Cancer Immunology and Immunotherapy, vol. 62, p. 919, 2013.

[120] R. Hannan, H. Zhang, A. Wallecha et al., "Combined immunotherapy with Listeria monocytogenes-based PSA vaccine and radiation therapy leads to a therapeutic response in a murine model of prostate Cancer," Cancer Immunology and Immunotherapy, vol. 61, p. 2227, 2012.

[121] Y. Li et al., "Prospects in adoptive cell transfer therapy for Cancer," Journal of Immunology and Clinical Research, vol. 1, p. 1008, 2013. 
[122] S. A. Rosenberg and M. E. Dudley, "Adoptive cell therapy for the treatment of patients with metastatic melanoma," Current Opinion in Immunology, vol. 21, no. 2, pp. 233-240, 2009.

[123] M. E. Dudley, J. C. Yang, R. Sherry et al., "Adoptive cell therapy for patients with metastatic melanoma: evaluation of intensive myeloablative chemoradiation preparative regimens," Journal of Clinical Oncology, vol. 26, no. 32, pp. 5233-5239, 2008.

[124] A. A. Rayner, E. A. Grimm, and M. T. Lotze, "Lymphokineactivated killer (LAK) cells. Analysis of factors relevant to the immunotherapy of human Cancer," Cancer, vol. 55, no. 6, pp. 1327-1333, 1985.

[125] D. Khayat, M. Weil, C. Soubrane, and C. Jacquillat, "LAK cells and Cancer immunotherapy," Bulletin du Cancer, vol. 75, no. 1, pp. 3-7, 1988.

[126] A. Belldegrun, I. Uppenkamp, and S. A. Rosenberg, "Antitumor reactivity of human lymphokine activated killer (LAK) cells against fresh and cultured preparations of renal cell Cancer," Journal of Urology, vol. 139, no. 1, pp. 150-155, 1988.

[127] H. Deng, "Anti-human lung giant cell Cancer (PG) effect of human LAK cells in vitro and in nude mice," Chinese Journal of Oncology, vol. 12, no. 4, pp. 258-260, 1990.

[128] M. Sacchi, D. Vitolo, P. Sedlmayr et al., "Induction of tumor regression in experimental model of human head and neck Cancer by human A-LAK cells and IL-2," International Journal of Cancer, vol. 47, no. 5, pp. 784-791, 1991.

[129] H. Takahashi, T. Nakada, and I. Puisieux, "Inhibition of human colon Cancer growth by antibody-directed human LAK cells in SCID mice," Science, vol. 259, no. 5100, pp. 1460-1463, 1993.

[130] S. Teraoka, S. Kyoizumi, T. Suzuki, M. Yamakido, and M. Akiyama, "Growth suppressive efficacy of human LAK cells against human lung Cancer implanted into SCID mice," International Journal of Oncology, vol. 6, no. 6, pp. 1271-1277, 1995.

[131] I. G. H. Schmidt-Wolf, R. S. Negrin, H.-P. Kiem, K. G. Blume, and I. L. Weissman, "Use of a SCID mouse/human lymphoma model to evaluate cytokine-induced killer cells with potent antitumor cell activity," Journal of Experimental Medicine, vol. 174, no. 1, pp. 139-149, 1991.

[132] F.-S. Wang, M.-X. Liu, B. Zhang et al., "Antitumor activities of human autologous cytokine-induced killer (CIK) cells against hepatocellular carcinoma cells in vitro and in vivo," World Journal of Gastroenterology, vol. 8, no. 3, pp. 464-468, 2002.

[133] J. Liu, J. Sui, Z. Zhang et al., "Inhibition of pleural metastasis of collecting duct carcinoma of the kidney by modified cytokineinduced killer cells: a case report and review of the literature," Oncology Letters, vol. 1, no. 6, pp. 955-958, 2010.

[134] W. Li, L. P. Xu, L. D. Zhao et al., "Cytokine-induced killer cell therapy for advanced pancreatic adenocarcinoma: a case report and review of the literature," Oncology Letters, vol. 5, p. 1427, 2013.

[135] Y. Ma, Z. Zhang, L. Tang et al., "Cytokine-induced killer cells in the treatment of patients with solid carcinomas: a systematic review and pooled analysis," Cytotherapy, vol. 14, no. 4, pp. 483493, 2012.

[136] C. Hontscha, Y. Borck, H. Zhou, D. Messmer, and I. G. H. Schmidt-Wolf, "Clinical trials on CIK cells: first report of the international registry on CIK cells (IRCC)," Journal of Cancer Research and Clinical Oncology, vol. 137, no. 2, pp. 305-310, 2011.

[137] S. Shi, R. Wang, Y. Chen, H. Song, L. Chen, and G. Huang, "Combining antiangiogenic therapy with adoptive cell immunotherapy exerts better antitumor effects in non-small cell lung Cancer models," PloS One, vol. 8, Article ID e65757, 2013.
[138] A. Märten, S. Renoth, M. Von Lilienfeld-Toal et al., "Enhanced lytic activity of cytokine-induced killer cells against multiple myeloma cells after co-culture with idiotype-pulsed dendritic cells," Haematologica, vol. 86, no. 10, pp. 1029-1037, 2001.

[139] H.-H. Zhu, K.-L. Xu, X.-Y. Pan, J.-Q. Liu, F.-X. Chen, and Y.-H. Huang, "Specific anti-leukemic cell effect mediated by dendritic cells pulsed with chronic myelogenous leukemia lysate antigen in vitro," Journal of Experimental Hematology, vol. 11, no. 3, pp. 278-281, 2003.

[140] A. Wongkajornsilp, S. Sangsuriyong, S. Hongeng, S. Waikakul, A. Asavamongkolkul, and S. Huabprasert, "Effective osteosarcoma cytolysis using cytokine-induced killer cells pre-inoculated with tumor RNA-pulsed dendritic cells," Journal of Orthopaedic Research, vol. 23, no. 6, pp. 1460-1466, 2005.

[141] W. Ge, C.-H. Li, W. Zhang et al., "Coculture of dendritic cell with cytokine-induced killer results in a significant increase in cytotoxic activity of CIK to tumor cells in vitro and in vivo," Zhonghua xue ye xue za zhi, vol. 25, no. 5, pp. 277-280, 2004.

[142] X.-J. Yang, J.-A. Huang, W. Lei, Y.-B. Zhu, and X.-G. Zhang, "Antitumor effects of cocultured dendritic cells and cytokineinduced killer cells on lung Cancer in vitro and in vivo," Chinese Journal of Cancer, vol. 25, no. 11, pp. 1329-1333, 2006.

[143] S. B. Shi, T. H. Ma, C. H. Li, and X. Y. Tang, "Effect of maintenance therapy with dendritic cells: cytokine-induced killer cells in patients with advanced non-small cell lung Cancer," Tumori, vol. 98, p. 314, 2012.

[144] Y. Yuanying, N. Lizhia, M. Feng et al., "Therapeutic outcomes of combining cryotherapy, chemotherapy and DC-CIK immunotherapy in the treatment of metastatic non-small cell lung Cancer," Cryobiology, vol. 67, p. 235, 2013.

[145] J. Ren et al., "Selections of appropriate regimen of highdose chemotherapy combined with adoptive cellular therapy with dendritic and cytokine-induced killer cells improved progression-free and overall survival in patients with metastatic breast Cancer: reargument of such contentious therapeutic preferences," Clinical and Translational Oncology, vol. 15, p. 780, 2013.

[146] Q.-C. Liu, W.-H. Wu, and G.-R. Li, "Effect of lingdankang composite combined dendritic cell-cytokine induced killer cells in treating leukemia," Chinese Journal of Integrated Traditional and Western Medicine, vol. 29, no. 4, pp. 347-350, 2009.

[147] Y. Liao, J. Ou, J. Deng et al., "Clinical implications of the tumorinfiltrating lymphocyte subsets in colorectal Cancer," Medical Oncology, vol. 30, p. 727, 2013.

[148] L. L. Perry, T. N. Wight, W. M. Collins, and W. R. Dunlop, "Differentiation of progressive versus regressive Rous virusinduced avian sarcomas according to tumor and infiltrating lymphocyte fine structure," Poultry science, vol. 57, no. 1, pp. 8084, 1978.

[149] T. Igarashi, H. Takahashi, T. Tobe et al., "Effect of tumorinfiltrating lymphocyte subsets on prognosis and susceptibility to interferon therapy in patients with renal cell carcinoma," Urologia Internationalis, vol. 69, no. 1, pp. 51-56, 2002.

[150] S. A. Rosenberg, P. Spiess, and R. Lafreniere, "A new approach to the adoptive immunotherapy of Cancer with tumor-infiltrating lymphocytes," Science, vol. 233, no. 4770, pp. 1318-1321, 1986.

[151] M. E. Dudley, J. R. Wunderlich, T. E. Shelton, J. Even, and S. A. Rosenberg, "Generation of tumor-infiltrating lymphocyte cultures for use in adoptive transfer therapy for melanoma patients," Journal of Immunotherapy, vol. 26, no. 4, pp. 332-342, 2003. 
[152] S. L. Goff, F. O. Smith, J. A. Klapper et al., "Tumor infiltrating lymphocyte therapy for metastatic melanoma: analysis of tumors resected for TIL," Journal of Immunotherapy, vol. 33, no. 8, pp. 840-847, 2010.

[153] J. H. Finke, P. Rayman, L. Hart et al., "Characterization of tumor-infiltrating lymphocyte subsets from human renal cell carcinoma: specific reactivity defined by cytotoxicity, interferon- $\gamma$ secretion, and proliferation," Journal of Immunotherapy, vol. 15, no. 2, pp. 91-104, 1994.

[154] Y. Chin, J. Janssens, J. Bleus, C. Vandevijver, J. Zhang, and J. Raus, "T cell receptor $\mathrm{V} \beta$ usage of tumor infiltrating lymphocyte lines cloned from human breast tumor and melanoma," International Journal of Oncology, vol. 7, no. 1, pp. 147-153, 1995.

[155] H. Yang, J. Li, Y. Zhao, and Z. Li, "Interaction of tumorinfiltrating lymphocyte from oral squamous cell carcinoma with FN enhances its adhesion and cytotoxicity," The Chinese Journal of Dental Research, vol. 2, no. 3-4, pp. 49-53, 1999.

[156] R. S. Freedman, B. Tomasovic, S. Templin et al., "Largescale expansion in interleukin-2 of tumor-infiltrating lymphocytes from patients with ovarian carcinoma for adoptive immunotherapy," Journal of Immunological Methods, vol. 167, no. 1-2, pp. 145-160, 1994.

[157] J. Zhou, M. E. Dudley, S. A. Rosenberg, and P. F. Robbins, "Selective growth, in vitro and in vivo, of individual T cell clones from tumor-infiltrating lymphocytes obtained from patients with melanoma," Journal of Immunology, vol. 173, no. 12, pp. 7622-7629, 2004.

[158] J. Zhou, M. E. Dudley, S. A. Rosenberg, and P. F. Robbins, "Persistence of multiple tumor-specific T-cell clones is associated with complete tumor regression in a melanoma patient receiving adoptive cell transfer therapy," Journal of Immunotherapy, vol. 28, no. 1, pp. 53-62, 2005.

[159] J. Zhou, X. Shen, J. Huang, R. J. Hodes, S. A. Rosenberg, and P. F. Robbins, "Telomere length of transferred lymphocytes correlates with in vivo persistence and tumor regression in melanoma patients receiving cell transfer therapy," Journal of Immunology, vol. 175, no. 10, pp. 7046-7052, 2005.

[160] K. Q. Tran, J. Zhou, K. H. Durflinger et al., "Minimally cultured tumor-infiltrating lymphocytes display optimal characteristics for adoptive cell therapy," Journal of Immunotherapy, vol. 31, no. 8, pp. 742-751, 2008.

[161] G. B. Ratto, P. Zino, S. Mirabelli et al., "A randomized trial of adoptive immunotherapy with tumor-infiltrating lymphocytes and interleukin-2 versus standard therapy in the postoperative treatment of resected nonsmall cell lung carcinoma," Cancer, vol. 78, p. 244, 1996.

[162] S. Turcotte, A. Gros, K. Hogan et al., "Phenotype and function of $\mathrm{T}$ cells infiltrating visceral metastases from gastrointestinal Cancers and melanoma: implications for adoptive cell transfer therapy," The Journal of Immunology, vol. 191, p. 2217, 2013.

[163] R. A. Morgan, M. E. Dudley, Y. Y. L. Yu et al., "High efficiency TCR gene transfer into primary human lymphocytes affords avid recognition of melanoma tumor antigen glycoprotein 100 and does not alter the recognition of autologous melanoma antigens," Journal of Immunology, vol. 171, no. 6, pp. 3287-3295, 2003.

[164] R. A. Morgan, L. A. Johnson, J. L. Davis et al., "Recognition of glioma stem cells by genetically modified $\mathrm{T}$ cells targeting EGFRvIII and development of adoptive cell therapy for glioma," Human Gene Therapy, vol. 23, p. 1043, 2012.
[165] L. A. Johnson, R. A. Morgan, M. E. Dudley et al., "Gene therapy with human and mouse T-cell receptors mediates Cancer regression and targets normal tissues expressing cognate antigen," Blood, vol. 114, no. 3, pp. 535-546, 2009.

[166] P. F. Robbins, R. A. Morgan, S. A. Feldman et al., "Tumor regression in patients with metastatic synovial cell sarcoma and melanoma using genetically engineered lymphocytes reactive with NY-ESO-1," Journal of Clinical Oncology, vol. 29, no. 7, pp. 917-924, 2011.

[167] H. Abken, P. Koehler, P. Schmidt, A. A. Hombach, and M. Hallek, "Engineered T cells for the adoptive therapy of b-cell chronic lymphocytic leukaemia," Advances in Hematology, vol. 2012, Article ID 595060, 13 pages, 2012.

[168] M. L. Davila, C. C. Kloss, G. Gunset, and M. Sadelain, “CD19 CAR-targeted T cells induce long-term remission and B Cell Aplasia in an immunocompetent mouse model of B cell acute lymphoblastic leukemia," PloS One, vol. 8, Article ID e61338, 2013.

[169] S. Gill and D. L. Porter, "CAR-modified anti-CD19 T cells for the treatment of B-cell malignancies: rules of the road," Expert Opinion on Biological Therapy, vol. 14, no. 1, pp. 37-49, 2014.

[170] Y. Chang and P. S. Moore, "Merkel cell carcinoma: a virusinduced human Cancer," Annual Review of Pathology: Mechanisms of Disease, vol. 7, pp. 123-144, 2012.

[171] S. Bhatia, O. Afanasiev, and P. Nghiem, "Immunobiology of Merkel cell carcinoma: implications for immunotherapy of a polyomavirus-associated Cancer," Current Oncology Reports, vol. 13, no. 6, pp. 488-497, 2011.

[172] H. Sihto and H. Joensuu, "Tumor-infiltrating lymphocytes and outcome in Merkel cell carcinoma, a virus-associated Cancer," Oncoimmunology, vol. 1, p. 1420, 2012.

[173] C. X. Zhang, Y. P. Lu, and Z. Y. Yu, "Hepatitis C virus RNA in tumor tissues of Chinese liver Cancer patients," Zhonghua yi xue za zhi, vol. 74, no. 11, pp. 673-709, 1994.

[174] M. Ringelhan, M. Heikenwalder, and U. Protzer, "Direct effects of hepatitis B virus-encoded proteins and chronic infection in liver Cancer development," Digestive Diseases, vol. 31, p. 138, 2013.

[175] T. R. Coelho, L. Almeida, and P. A. Lazo, "JC virus in the pathogenesis of colorectal Cancer, an etiological agent or another component in a multistep process?" Virology Journal, vol. 7, article no. 42, 2010.

[176] X. Mou, L. Chen, F. Liu et al., "Prevalence of JC virus in Chinese patients with colorectal Cancer," PloS One, vol. 7, Article ID e35900, 2012.

[177] A. Vilkin, Z. Ronen, Z. Levi, S. Morgenstern, M. Halpern, and Y. Niv, "Presence of JC virus DNA in the tumor tissue and normal mucosa of patients with sporadic colorectal Cancer (CRC) or with positive family history and Bethesda criteria," Digestive Diseases and Sciences, vol. 57, no. 1, pp. 79-84, 2012.

[178] A. Merlo, R. Turrini, R. Dolcetti et al., “The interplay between Epstein-Barr virus and the immune system: a rationale for adoptive cell therapy of EBV-related disorders," Haematologica, vol. 95 , no. 10, pp. 1769-1777, 2010.

[179] J. Duraiswamy, M. Sherritt, S. Thomson et al., "Therapeutic LMP1 polyepitope vaccine for EBV-associated Hodgkin disease and nasopharyngeal carcinoma," Blood, vol. 101, no. 8, pp. 31503156, 2003.

[180] J. I. Cohen, A. S. Fauci, H. Varmus, and G. J. Nabel, "EpsteinBarr virus: an important vaccine target for Cancer prevention," Science Translational Medicine, vol. 3, no. 107, Article ID 107fs7, 2011. 
[181] L. Goodman, "EBV conference establishes goals for defining disease-related EBV subtypes for vaccine development," Chinese Journal of Cancer, vol. 28, no. 12, pp. 1233-1235, 2009.

[182] J. A. Kanakry and R. F. Ambinder, "EBV-related lymphomas: new approaches to treatment," Current Treatment Options in Oncology, vol. 14, p. 224, 2013.

[183] R. C. Gallo, "Research and discovery of the first human Cancer virus, HTLV-1," Best Practice and Research: Clinical Haematology, vol. 24, no. 4, pp. 559-565, 2011.

[184] M. P. Lynch and P. T. P. Kaumaya, "Advances in HTLV-1 peptide vaccines and therapeutics," Current Protein and Peptide Science, vol. 7, no. 2, pp. 137-145, 2006.

[185] K. Tezuka, R. Xun, M. Tei et al., "An animal model of adult T-cell leukemia-humanized mice with HTLV-1 specific immunity," Blood, vol. 123, no. 3, pp. 346-355, 2014.

[186] D. Zhao, P. Chen, H. Yang et al., "Live attenuated measles virus vaccine induces apoptosis and promotes tumor regression in lung Cancer," Oncology Reports, vol. 29, p. 199, 2013.

[187] F. Yang and X.-F. Yang, "New concepts in tumor antigens: their significance in future immunotherapies for tumors," Cellular \& molecular immunology, vol. 2, no. 5, pp. 331-341, 2005.

[188] N. Phougat, N. Phougat, S. Khatri, A. Singh et al., "Combination Therapy: the propitious rationale for drug development," Combinatorial Chemistry \& High Throughput Screening, vol. 17, no. 1, pp. 53-67, 2014.

[189] S. Baek, C.-S. Kim, S.-B. Kim et al., "Combination therapy of renal cell carcinoma or breast Cancer patients with dendritic cell vaccine and IL-2: results from a phase I/II trial," Journal of Translational Medicine, vol. 9, no. 1, article no. 178, 2011. 


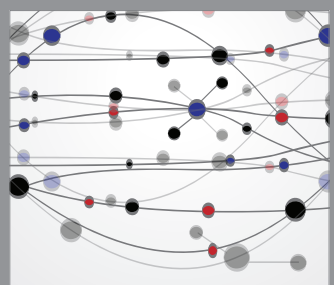

The Scientific World Journal
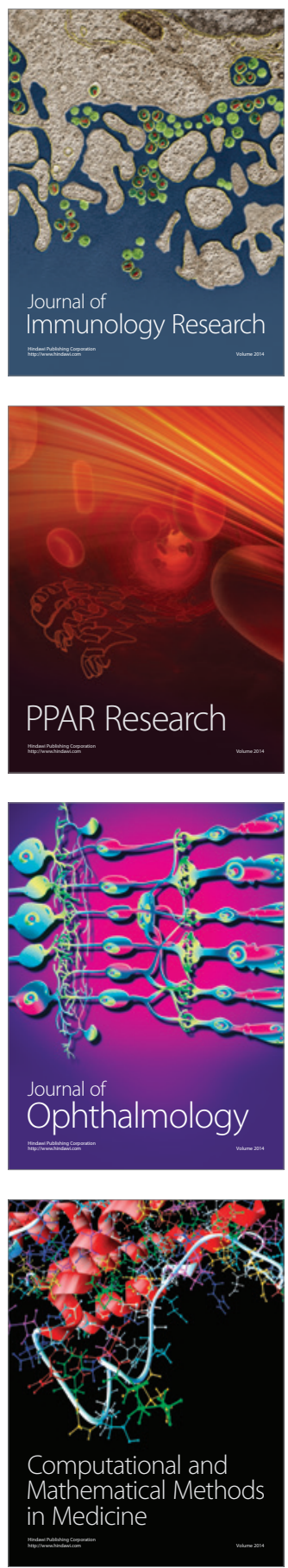

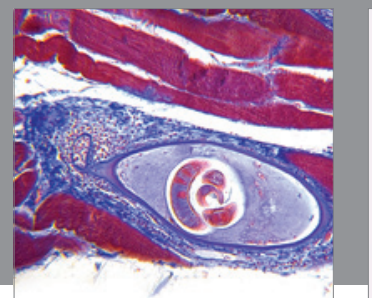

Gastroenterology

Research and Practice
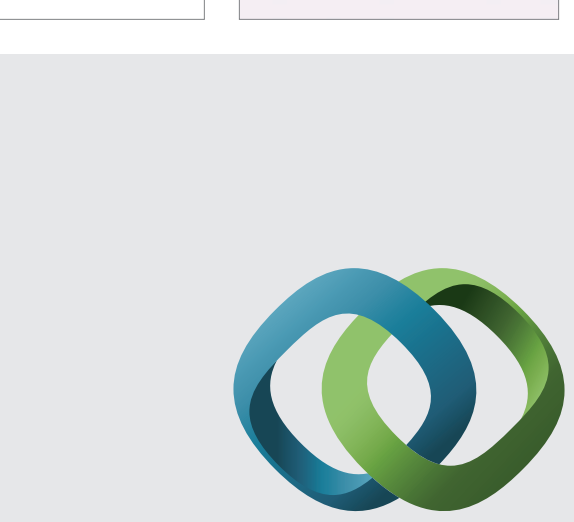

\section{Hindawi}

Submit your manuscripts at

http://www.hindawi.com
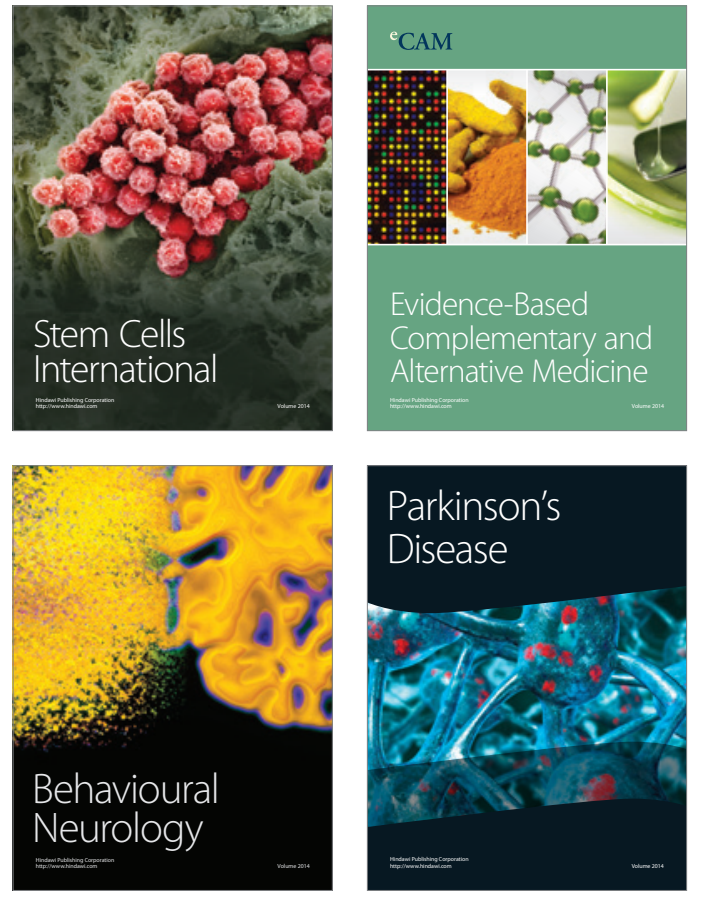
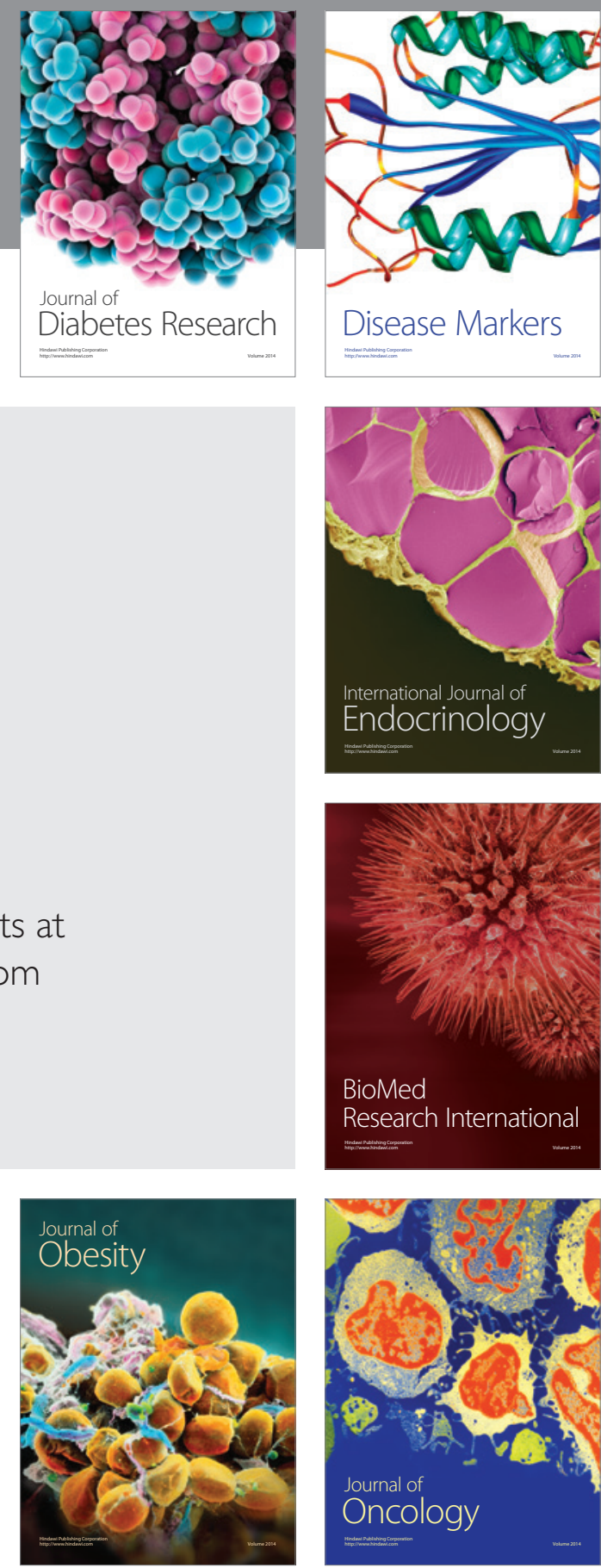

Disease Markers
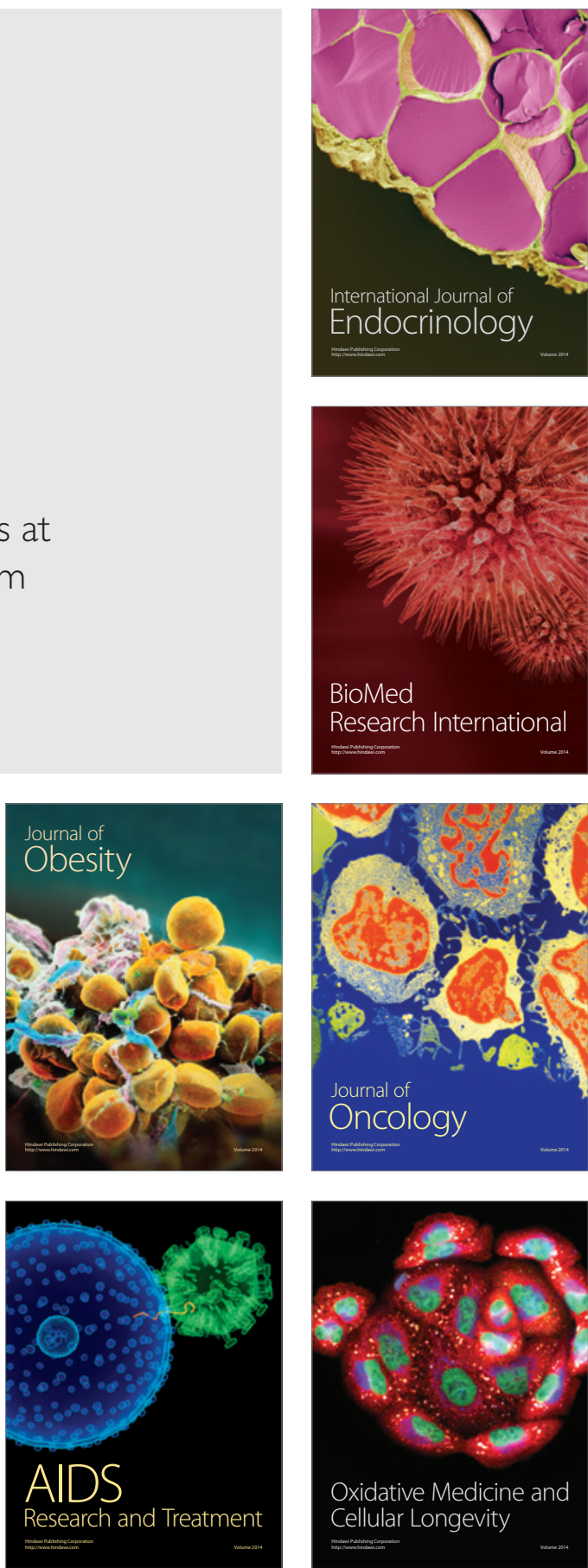